\title{
Burden of Liver Cancer Attributable to Five Risk Factors by Specific Etiologies in 204 Countries and Territories
}

\section{Yizhen Li \\ Xi'an Jiaotong University Second Affiliated Hospital}

\section{Bajin Wei}

Zhejiang University School of Medicine First Affiliated Hospital

\section{Yujiao Deng}

Xi'an Jiaotong University Second Affiliated Hospital Department of Oncology

Yuanxing Liu

Zhejiang University School of Medicine First Affiliated Hospital

\section{Xinyue Deng}

Zhejiang University School of Medicine First Affiliated Hospital

\section{Dong Xiang}

MCMC Celilo Cancer Center: Mid-Columbia Medical Center Celilo Cancer Center

Jingjing $\mathrm{Hu}$

Harvard Medical School

\section{Yi Zheng}

Xi'an Jiaotong University Second Affiliated Hospital

\section{Peng Xu}

Xi'an Jiaotong University Second Affiliated Hospital

Jia Yao

Zhejiang University School of Medicine First Affiliated Hospital

Zhen Zhai

Xi'an Jiaotong University Second Affiliated Hospital

\section{Linghui Zhou}

Zhejiang University School of Medicine First Affiliated Hospital

\section{Si Yang}

Xi'an Jiaotong University Second Affiliated Hospital

\section{Ying Wu}

Xi'an Jiaotong University Second Affiliated Hospital

\section{Shusen Zheng}

Zhejiang University School of Medicine First Affiliated Hospital

\section{Zhijun Dai ( $\nabla$ dzj0911@126.com )}

Zhejiang University School of Medicine First Affiliated Hospital https://orcid.org/0000-0001-5209-8626

\section{Research}

Keywords: liver cancer, risk factors, GBD study, alcohol use, drug use

Posted Date: July 26th, 2021

DOI: https://doi.org/10.21203/rs.3.rs-680961/v1 
License: (c) (i) This work is licensed under a Creative Commons Attribution 4.0 International License. Read Full License 


\section{Abstract}

Background Liver cancer has caused a serious disease burden worldwide wherein prognostic risk factors may have had a significant role. However, previous studies have focused on liver cancer distributions and trend variations without analyzing the role of risk factors.

Methods We assessed liver cancer burden attributable to five recognized risk factors as well as temporal trends from 1990 to 2019 based on the 2019 Global Burden of Disease Study. The risk exposure levels and their contributed burden were estimated by cause, sex, age, and location. Furthermore, the relationship between the risks and social-demographic index (SDI) was investigated.

Results The total liver cancer burden attributable to risk factors is still increasing year by year in terms of death and disabilityadjusted life years. However, the burden attributable to alcohol use and smoking has shown a downward trend in recent years. Risk-related burden in males was more than three times as that in females, the burden among the middle-aged and elderly was the most serious, and Central Asia, high-income Asia Pacific and East Asia exhibited the highest burden worldwide. The exposure levels of the five recognized risk factors were generally positively correlated with SDI value. However, the risk-related liver cancer burden first increased and then decreased with the SDI value.

Conclusion These findings could help in understanding the role of prognostic risk factors in liver cancer burden, in promoting the development of relevant studies, and in proposing better prevention and control policies tailored to local conditions.

\section{Background}

Liver cancer (LC) was one of the leading causes of cancer death, causing approximately 8.2 million cancer deaths globally, ranking only after lung, colorectal, and gastric cancers in 2017[1]. Published epidemiological studies have extensively investigated and provided in-depth understanding of the potential etiologies of LC[2], with the prevalence of different etiologies in different regions, driving LC heterogeneity. For instance, endemic and chronic HBV infection has been the main cause of LC in China[3], whereas in South Korea and Japan, HCV infection is the main driver of LC[4]. The Global Burden of Disease (GBD) study assessed the contribution of various risk factors to different kinds of diseases and health problems, and Liu et al. described a global landscape of primary LC with respect to four main etiologies based on data from GBD 2016[5]. However, the role of risk factors for LC burden has not been fully emphasized to date.

In the current study, we assessed the burden of LC attributable to particular risk factors and examined temporal trends from 1990 to 2019, as well as the exposure level and distribution of the recognized risk factors at the global, regional, and national levels. These findings could serve as an important supplement for and extension of previous studies on LC epidemiology and also provide assistance to policy-making in terms of improving LC prognosis catered to different regions and countries.

\section{Materials And Methods}

\section{Data sources}

Data on the risk factors for LC burden were collected from the Global Health Data Exchange GBD Results Tool (http://ghdx.healthdata.org/gbd-results-tool), which is a catalog of global health and demographic data created by GBD collaborators. This tool provides a comparative assessment of health loss from 369 diseases and 87 risk factors across 204 countries and territories within $21 \mathrm{GBD}$ regions[6]. We collected the annual deaths and disability-adjusted life years (DALYs) for LC with respect to risk factors and age-standardized rates (ASRs) from 1990 to 2019, by sex, age group, region, country, and etiologies (alcohol use, hepatitis B, hepatitis $\mathrm{C}$, nonalcoholic steatohepatitis (NASH), and other causes), and the summary exposure level of each risk factor was also obtained.

\section{Exposure Level Estimates}


There are five types of LC by different etiologies, namely liver cancer due to alcohol use (LCAU), liver cancer due to NASH (LCNA), liver cancer due to hepatitis B (LCHB), liver cancer due to hepatitis C (LCHC), and liver cancer due to other causes (LCOC). Five recognized risk factors, including alcohol use, drug use, high body mass index (BMI), high fasting plasma glucose, and smoking, are closely related to LC burden through a comparative risk assessment framework. Summary exposure value (SEV) was applied to estimate the population level exposure, which is a measure of a population's risk-weighted exposure or the risk-weighted prevalence of a separate risk factor[7]. The age-standardized SEV rate was used in this research, which ranges from $0 \%$ (no risk of exposure) to $100 \%$ (maximum risk possibility for the entire population).

\section{Estimation Of Lc Burden Attributable To Risk Factors}

The indicators used to estimate LC burden included the number of deaths, years of life lost, years lived with disability, and DALYs[8]. The five risk factors and five types of LC constituted several risk-outcome pairs, and for a given risk-outcome pair, the risk exposure and the related cancer burden were estimated by age, gender, region, and social development.

Social development was evaluated using the social-demographic index (SDI), which was calculated based on fertility rate, average schooling years (for people aged $\geq 15$ years old), and per capita after-tax income distribution. Each GBD location has an annual SDI score, and countries are divided into five SDI quintiles (high, high-medium, medium, medium-low, and low levels). The relationship between a location's risk attributed LC burden and the corresponding SDI value was investigated.

\section{Statistical Analyses}

All indicator estimates were presented with $95 \%$ uncertainty intervals (UIs) to ensure that all the sources of uncertainty have been captured. A 95\% Ul excluding 0 was considered statistically significant. All statistical analyses were performed using the R program (Version 4.0.2, R core team).

\section{Results}

\section{Risk factors attributable to LC burden}

In 2019 , there were 484,577 ( $95 \%$ Ul: 444,091 to 525,798$)$ LC deaths and $12,528,422(11,400,671$ to $13,687,675)$ LC DALYs globally, with nearly half of these being attributed to the five risk factors. Among the 254.7 thousand risk attributed LC deaths, alcohol use accounted for $30.4 \%$, smoking accounted for $27.2 \%$, drug use accounted for $20.6 \%$, high BMI accounted for $20.6 \%$, and high fasting plasma glucose accounted for the remaining 1.3\% (Table 1). In 2019, the ASR of the total risk attributed LC deaths and DALYs were 3.1 (2.7 to 3.6) per 100,000 persons and 75.0 (63.0 to 88.2) per 100,000 persons, respectively. 
Table 1

Global liver cancer deaths and DALYs attributable to risk factors by specific etiologies for both sexes combined in 2019 and percentage change from 1990 to 2019.

\begin{tabular}{|c|c|c|c|c|c|c|c|c|}
\hline \multirow{2}{*}{$\begin{array}{l}\text { Risk- } \\
\text { outcome } \\
\text { pairs }\end{array}$} & \multicolumn{4}{|l|}{ Deaths } & \multicolumn{4}{|l|}{ DALYs } \\
\hline & $\begin{array}{l}2019 \\
\text { all } \\
\text { ages } \\
\text { number } \\
\left(\times 10^{3}\right)\end{array}$ & $\begin{array}{l}\text { Change\% } \\
\text { in all } \\
\text { ages } \\
\text { number, } \\
1990- \\
2019\end{array}$ & $\begin{array}{l}2019 \text { age- } \\
\text { standardized } \\
\text { rate per } \\
100,000 \\
\text { people }\end{array}$ & $\begin{array}{l}\text { Change\% in } \\
\text { age- } \\
\text { standardized } \\
\text { rate, 1990- } \\
2019\end{array}$ & $\begin{array}{l}2019 \\
\text { all } \\
\text { ages } \\
\text { number } \\
\left(\times 10^{6}\right)\end{array}$ & $\begin{array}{l}\text { Change\% } \\
\text { in all } \\
\text { ages } \\
\text { number, } \\
1990- \\
2019\end{array}$ & $\begin{array}{l}2019 \text { age- } \\
\text { standardized } \\
\text { rate per } \\
100,000 \\
\text { people }\end{array}$ & $\begin{array}{l}\text { Change\% in } \\
\text { age- } \\
\text { standardized } \\
\text { rate, 1990- } \\
2019\end{array}$ \\
\hline \multirow{2}{*}{$\begin{array}{l}\text { Liver } \\
\text { cancer }\end{array}$} & 254.7 & 65.1 & 3.1 & -18.6 & 6.3 & 44.0 & 75.0 & -27.3 \\
\hline & $\begin{array}{l}(218.2 \\
\text { to } \\
297.1)\end{array}$ & $\begin{array}{l}(42.7 \text { to } \\
92.7)^{\star}\end{array}$ & (2.7 to 3.6$)$ & $\begin{array}{l}(-29.3 \\
\text { to-5.5)* }\end{array}$ & $\begin{array}{l}(5.3 \text { to } \\
7.4)\end{array}$ & $\begin{array}{l}(22.4 \text { to } \\
70.2)^{\star}\end{array}$ & $\begin{array}{l}(63.0 \text { to } \\
88.2)\end{array}$ & $\begin{array}{l}(-38.0 \\
\text { to }-14.3)^{*}\end{array}$ \\
\hline \multirow[t]{2}{*}{ Smoking } & 85.9 & 12.9 & 1.0 & -36.5 & 2.1 & 13.6 & 25.3 & -43.1 \\
\hline & $\begin{array}{l}(50.0 \text { to } \\
123.0)\end{array}$ & $\begin{array}{l}(-8.6 \text { to } \\
56.2)\end{array}$ & (0.9 to 1.4 ) & $\begin{array}{l}(-47.5 \\
\text { to }-23.1)^{*}\end{array}$ & $\begin{array}{l}(1.2 \text { to } \\
3.1)\end{array}$ & $\begin{array}{l}(-8.2 \text { to } \\
42.6)\end{array}$ & $\begin{array}{l}(13.8 \text { to } \\
36.5)\end{array}$ & $\begin{array}{l}(-53.7 \\
\text { to }-29.5)^{*}\end{array}$ \\
\hline \multirow{2}{*}{$\begin{array}{l}\text { Alcohol } \\
\text { use }\end{array}$} & 96.1 & 77.7 & 1.2 & -12.8 & 2.4 & 56.0 & 28.4 & -21.1 \\
\hline & $\begin{array}{l}\text { (77.5 to } \\
116.2)\end{array}$ & $\begin{array}{l}(53.9 \text { to } \\
102.2)^{*}\end{array}$ & (0.9 to 1.4 ) & $\begin{array}{l}(-24.0 \\
\text { to }-1.3)^{\star}\end{array}$ & $\begin{array}{l}(1.9 \text { to } \\
2.9)\end{array}$ & $\begin{array}{l}(31.4 \text { to } \\
82.0)^{\star}\end{array}$ & $\begin{array}{l}(22.9 \text { to } \\
34.5)\end{array}$ & $\begin{array}{l}(-32.9 \\
\text { to }-8.6)^{\star}\end{array}$ \\
\hline \multirow[t]{2}{*}{ Drug use } & 71.5 & 85.5 & 0.9 & -8.0 & 1.6 & 55.5 & 19.4 & -22.0 \\
\hline & $\begin{array}{l}(57.1 \text { to } \\
89.2)\end{array}$ & $\begin{array}{l}(56.2 \text { to } \\
121.3)^{*}\end{array}$ & (0.7 to 1.1$)$ & $\begin{array}{l}(-22.8 \text { to } \\
9.6)\end{array}$ & $\begin{array}{l}(1.3 \text { to } \\
2.0)\end{array}$ & $\begin{array}{l}(32.4 \text { to } \\
85.6)^{\star}\end{array}$ & $\begin{array}{l}(15.6 \text { to } \\
23.9)\end{array}$ & $\begin{array}{l}(-33.6 \\
\text { to }-7.0)^{\star}\end{array}$ \\
\hline \multirow{2}{*}{$\begin{array}{l}\text { High } \\
\text { fasting } \\
\text { plasma } \\
\text { glucose }\end{array}$} & 4.7 & 40.6 & 0.1 & 13.0 & 0.1 & 105.5 & 1.2 & 1.1 \\
\hline & $\begin{array}{l}(1.2 \text { to } \\
10.4)\end{array}$ & $\begin{array}{l}(32.0 \text { to } \\
51.1)^{\star}\end{array}$ & (0.0 to 0.1$)$ & $\begin{array}{l}(-1.6 \text { to } \\
32.7)\end{array}$ & $\begin{array}{l}(0.0 \text { to } \\
0.2)\end{array}$ & $\begin{array}{l}(76.5 \text { to } \\
276.4)^{*}\end{array}$ & (0.3 to 2.6 ) & $\begin{array}{l}(-13.0 \text { to } \\
20.3)\end{array}$ \\
\hline \multirow{2}{*}{$\begin{array}{l}\text { High } \\
\text { body- } \\
\text { mass } \\
\text { index }\end{array}$} & 60.8 & 162.3 & 0.7 & 28.9 & 1.6 & 137.7 & 19.2 & 21.0 \\
\hline & $\begin{array}{l}\text { (24.2 to } \\
114.6)\end{array}$ & $\begin{array}{l}(99.9 \text { to } \\
297.6)^{*}\end{array}$ & (0.3 to 1.4 ) & $\begin{array}{l}(-1.1 \text { to } \\
93.4)^{\star}\end{array}$ & $\begin{array}{l}(0.6 \text { to } \\
3.0)\end{array}$ & $\begin{array}{l}(76.2 \text { to } \\
276.4)^{\star}\end{array}$ & (7.6 to 36.4 ) & $\begin{array}{l}(-9.9 \text { to } \\
89.8)^{\star}\end{array}$ \\
\hline \multirow{2}{*}{$\begin{array}{l}\text { Liver } \\
\text { cancer } \\
\text { due to } \\
\text { hepatitis } \\
\text { B }\end{array}$} & 62.5 & 22.6 & 0.8 & -38.3 & 1.9 & 12.7 & 22.1 & -41.9 \\
\hline & $\begin{array}{l}(40.3 \text { to } \\
86.1)\end{array}$ & $\begin{array}{l}(-7.2 \text { to } \\
63.0)\end{array}$ & (0.5 to 1.0$)$ & $\begin{array}{l}(-52.9 \\
\text { to }-18.0)^{*}\end{array}$ & $\begin{array}{l}(1.2 \text { to } \\
2.6)\end{array}$ & $\begin{array}{l}(-15.3 \text { to } \\
52.9)\end{array}$ & $\begin{array}{l}(14.0 \text { to } \\
30.5)\end{array}$ & $\begin{array}{l}(-56.3 \\
\text { to }-21.4)^{*}\end{array}$ \\
\hline \multirow[t]{2}{*}{ Smoking } & 38.1 & 27.0 & 0.5 & -48.6 & 1.1 & -5.9 & 12.6 & -52.4 \\
\hline & $\begin{array}{l}(20.9 \text { to } \\
56.4)\end{array}$ & $\begin{array}{l}(-3.1 \text { to } \\
114.4)\end{array}$ & (0.3 to 0.7 ) & $\begin{array}{l}(-60.1 \\
\text { to-32.7)* }\end{array}$ & $\begin{array}{l}(0.6 \text { to } \\
1.6)\end{array}$ & $\begin{array}{l}(-28.1 \text { to } \\
26.8)\end{array}$ & (6.7 to 19.2 ) & $\begin{array}{l}(-63.5 \\
\text { to-36.3)* }\end{array}$ \\
\hline \multirow{2}{*}{$\begin{array}{l}\text { Alcohol } \\
\text { use }\end{array}$} & 4.6 & -17.9 & 0.1 & -56.0 & 0.2 & -21.8 & 2.2 & -56.9 \\
\hline & $\begin{array}{l}\text { (0.2 to } \\
11.7)\end{array}$ & $\begin{array}{l}(-49.2 \text { to } \\
82.4)\end{array}$ & (0.0 to 0.1$)$ & $\begin{array}{l}(-72.1 \text { to } \\
8.7)\end{array}$ & $\begin{array}{l}(0.0 \text { to } \\
0.4)\end{array}$ & $\begin{array}{l}(-50.6 \text { to } \\
72.7)\end{array}$ & (0.1 to 5.2 ) & $\begin{array}{l}(-72.0 \text { to } \\
6.2)\end{array}$ \\
\hline \multirow[t]{2}{*}{ Drug use } & 3.1 & 77.4 & 0.0 & -9.8 & 0.1 & 60.1 & 1.1 & -16.8 \\
\hline & $\begin{array}{l}(2.1 \text { to } \\
4.6)\end{array}$ & $\begin{array}{l}\text { (36.9 to } \\
128.3)^{*}\end{array}$ & (0.0 to 0.1$)$ & $\begin{array}{l}(-30.0 \text { to } \\
16.0)\end{array}$ & $\begin{array}{l}(0.0 \text { to } \\
0.1)\end{array}$ & $\begin{array}{l}\text { (23.5 to } \\
108.0)^{\star}\end{array}$ & (0.7 to 1.6$)$ & $\begin{array}{l}(-36.0 \text { to } \\
8.1)\end{array}$ \\
\hline
\end{tabular}

*indicates statistically significant change.

Abbreviations: DALYs = disability-adjusted life years; $\mathrm{NASH}=$ non-alcoholic steatohepatitis 


\begin{tabular}{|c|c|c|c|c|c|c|c|c|}
\hline \multirow{2}{*}{$\begin{array}{l}\text { Risk- } \\
\text { outcome } \\
\text { pairs }\end{array}$} & \multicolumn{4}{|l|}{ Deaths } & \multicolumn{4}{|l|}{ DALYs } \\
\hline & $\begin{array}{l}2019 \\
\text { all } \\
\text { ages } \\
\text { number } \\
\left(\times 10^{3}\right)\end{array}$ & $\begin{array}{l}\text { Change\% } \\
\text { in all } \\
\text { ages } \\
\text { number, } \\
1990- \\
2019\end{array}$ & $\begin{array}{l}2019 \text { age- } \\
\text { standardized } \\
\text { rate per } \\
100,000 \\
\text { people }\end{array}$ & $\begin{array}{l}\text { Change\% in } \\
\text { age- } \\
\text { standardized } \\
\text { rate, 1990- } \\
2019\end{array}$ & $\begin{array}{l}2019 \\
\text { all } \\
\text { ages } \\
\text { number } \\
\left(\times 10^{6}\right)\end{array}$ & $\begin{array}{l}\text { Change\% } \\
\text { in all } \\
\text { ages } \\
\text { number, } \\
1990- \\
2019\end{array}$ & $\begin{array}{l}2019 \text { age- } \\
\text { standardized } \\
\text { rate per } \\
100,000 \\
\text { people }\end{array}$ & $\begin{array}{l}\text { Change\% in } \\
\text { age- } \\
\text { standardized } \\
\text { rate, 1990- } \\
2019\end{array}$ \\
\hline \multirow{2}{*}{$\begin{array}{l}\text { High } \\
\text { body- } \\
\text { mass } \\
\text { index }\end{array}$} & 24.1 & 122.9 & 0.3 & 13.1 & 0.7 & 106.0 & 8.9 & 7.6 \\
\hline & $\begin{array}{l}\text { (8.7 to } \\
48.3)\end{array}$ & $\begin{array}{l}(56.9 \text { to } \\
293.8)^{\star}\end{array}$ & (0.1 to 0.6$)$ & $\begin{array}{l}(-20.0 \text { to } \\
98.1)\end{array}$ & $\begin{array}{l}(0.3 \text { to } \\
1.5)\end{array}$ & $\begin{array}{l}\text { (42.0 to } \\
271.0)^{\star}\end{array}$ & (3.2 to 17.5 ) & $\begin{array}{l}(-25.5 \text { to } \\
93.1)\end{array}$ \\
\hline \multirow{2}{*}{$\begin{array}{l}\text { Liver } \\
\text { cancer } \\
\text { due to } \\
\text { hepatitis } \\
\text { C }\end{array}$} & 87.0 & 82.9 & 1.1 & -10.8 & 1.9 & 55.4 & 22.7 & -22.8 \\
\hline & $\begin{array}{l}\text { (70.7 to } \\
104.8)\end{array}$ & $\begin{array}{l}\text { (59.1 to } \\
111.5)^{*}\end{array}$ & (0.9 to 1.3 ) & $\begin{array}{l}(-22.3 \text { to } \\
2.9)\end{array}$ & $\begin{array}{l}(1.5 \text { to } \\
2.3)\end{array}$ & $\begin{array}{l}\text { (35.3 to } \\
80.8)^{\star}\end{array}$ & $\begin{array}{l}(18.6 \text { to } \\
27.3)\end{array}$ & $\begin{array}{l}(-32.7 \\
\text { to-10.5)* }\end{array}$ \\
\hline \multirow[t]{2}{*}{ Smoking } & 21.9 & 55.7 & 0.5 & 1.7 & 0.5 & 36.1 & 5.5 & -33.6 \\
\hline & $\begin{array}{l}(12.5 \text { to } \\
31.7)\end{array}$ & $\begin{array}{l}(36.1 \text { to } \\
80.2)\end{array}$ & (0.3 to 0.7 ) & $\begin{array}{l}(-13.7 \text { to } \\
21.9)\end{array}$ & $\begin{array}{l}(0.2 \text { to } \\
0.7)\end{array}$ & $\begin{array}{l}(19.5 \text { to } \\
56.5)^{\star}\end{array}$ & (3.0 to 7.9 ) & $\begin{array}{l}(-41.5 \\
\text { to }-24.0)^{*}\end{array}$ \\
\hline \multirow{2}{*}{$\begin{array}{l}\text { Alcohol } \\
\text { use }\end{array}$} & 0.7 & 16.5 & 0.0 & -40.2 & 0.0 & -9.9 & 0.2 & -53.5 \\
\hline & $\begin{array}{l}(0.0 \text { to } \\
2.6)\end{array}$ & $\begin{array}{l}(-34.0 \text { to } \\
135.6)\end{array}$ & $(0.0$ to 0.0$)$ & $\begin{array}{l}(-64.6 \text { to } \\
24.4)\end{array}$ & $\begin{array}{l}(0.0 \text { to } \\
0.1)\end{array}$ & $\begin{array}{l}(-41.5 \text { to } \\
100.0)\end{array}$ & (0.0 to 0.7$)$ & $\begin{array}{l}(-69.4 \text { to } \\
10.3)\end{array}$ \\
\hline \multirow[t]{2}{*}{ Drug use } & 68.3 & 85.9 & 0.8 & -7.9 & 1.5 & 41.4 & 18.3 & -22.3 \\
\hline & $\begin{array}{l}(54.6 \text { to } \\
85.4)\end{array}$ & $\begin{array}{l}(56.2 \text { to } \\
121.8)^{*}\end{array}$ & (0.7 to 1.1$)$ & $\begin{array}{l}(-22.8 \text { to } \\
9.8)\end{array}$ & $\begin{array}{l}(1.2 \text { to } \\
1.9)\end{array}$ & $\begin{array}{l}(27.9 \text { to } \\
58.0)^{\star}\end{array}$ & $\begin{array}{l}(14.7 \text { to } \\
22.6)\end{array}$ & $\begin{array}{l}(-34.1 \\
\text { to }-7.1)^{*}\end{array}$ \\
\hline \multirow{2}{*}{$\begin{array}{l}\text { High } \\
\text { body- } \\
\text { mass } \\
\text { index }\end{array}$} & 19.1 & 189.5 & 0.2 & 36.4 & 0.4 & 164.8 & 5.1 & 29.1 \\
\hline & $\begin{array}{l}(7.6 \text { to } \\
35.4)\end{array}$ & $\begin{array}{l}(137.2 \text { to } \\
302.4)^{\star}\end{array}$ & (0.1 to 0.4 ) & $\begin{array}{l}(12.1 \text { to } \\
89.3)^{\star}\end{array}$ & $\begin{array}{l}(0.2 \text { to } \\
0.8)\end{array}$ & $\begin{array}{l}(111.8 \text { to } \\
279.4)^{\star}\end{array}$ & (2.0 to 9.2 ) & $\begin{array}{l}(3.4 \text { to } \\
84.5)^{\star}\end{array}$ \\
\hline \multirow{2}{*}{$\begin{array}{l}\text { Liver } \\
\text { cancer } \\
\text { due to } \\
\text { alcohol } \\
\text { use }\end{array}$} & 90.7 & 89.6 & 1.1 & -8.0 & 2.2 & 71.1 & 26.1 & -14.8 \\
\hline & $\begin{array}{l}\text { (73.3 to } \\
109.4)\end{array}$ & $\begin{array}{l}\text { (71.7 to } \\
110.5)^{\star}\end{array}$ & (0.9 to 1.3 ) & $\begin{array}{l}(-16.5 \text { to } \\
1.8)\end{array}$ & $\begin{array}{l}(1.8 \text { to } \\
2.7)\end{array}$ & $\begin{array}{l}\text { (53.9 to } \\
91.5)^{\star}\end{array}$ & $\begin{array}{l}(21.1 \text { to } \\
31.6)\end{array}$ & $\begin{array}{l}(-23.1 \\
\text { to }-4.8)^{*}\end{array}$ \\
\hline \multirow[t]{2}{*}{ Smoking } & 17.7 & 72.8 & 0.2 & -16.6 & 0.4 & 58.2 & 4.9 & -22.3 \\
\hline & $\begin{array}{l}(9.7 \text { to } \\
26.2)\end{array}$ & $\begin{array}{l}\text { (53.2 to } \\
95.5)^{\star}\end{array}$ & (0.1 to 0.3 ) & $\begin{array}{l}(-25.8 \\
\text { to-6.5) }\end{array}$ & $\begin{array}{l}(0.2 \text { to } \\
0.6)\end{array}$ & $\begin{array}{l}(40.4 \text { to } \\
79.7)^{\star}\end{array}$ & (2.7 to 7.4 ) & $\begin{array}{l}(-30.9 \text { to } \\
17.0)\end{array}$ \\
\hline \multirow{2}{*}{$\begin{array}{l}\text { Alcohol } \\
\text { use }\end{array}$} & 90.7 & 89.6 & 1.1 & -8.0 & 2.2 & 71.1 & 26.1 & -14.8 \\
\hline & $\begin{array}{l}\text { (73.3 to } \\
109.4)\end{array}$ & $\begin{array}{l}\text { (71.7 to } \\
110.5)^{*}\end{array}$ & (0.9 to 1.3 ) & $\begin{array}{l}(-16.5 \text { to } \\
1.8)\end{array}$ & $\begin{array}{l}(1.8 \text { to } \\
2.7)\end{array}$ & $\begin{array}{l}(53.9 \text { to } \\
91.5)^{\star}\end{array}$ & $\begin{array}{l}(21.1 \text { to } \\
31.6)\end{array}$ & $\begin{array}{l}(-23.1 \\
\text { to-12.4)* }\end{array}$ \\
\hline \multirow{2}{*}{$\begin{array}{l}\text { High } \\
\text { body- } \\
\text { mass } \\
\text { index }\end{array}$} & 14.6 & 221.5 & 0.2 & 54.9 & 0.4 & 204.3 & 4.3 & 50.3 \\
\hline & $\begin{array}{l}(5.6 \text { to } \\
28.3)\end{array}$ & $\begin{array}{l}(167.0 \text { to } \\
314.9)^{\star}\end{array}$ & (0.1 to 0.3 ) & $\begin{array}{l}(29.0 \text { to } \\
99.1)^{\star}\end{array}$ & $\begin{array}{l}(0.2 \text { to } \\
0.7)\end{array}$ & $\begin{array}{l}(148.6 \text { to } \\
300.4)^{\star}\end{array}$ & (1.6 to 8.2 ) & $\begin{array}{l}(23.0 \text { to } \\
97.4)^{\star}\end{array}$ \\
\hline \multirow{2}{*}{$\begin{array}{l}\text { Liver } \\
\text { cancer } \\
\text { due to } \\
\text { NASH }\end{array}$} & 7.5 & 118.9 & 0.1 & 4.3 & 0.2 & 92.5 & 1.9 & -5.7 \\
\hline & $\begin{array}{l}(4.3 \text { to } \\
11.7)\end{array}$ & $\begin{array}{l}\text { (83.3 to } \\
157.8)^{\star}\end{array}$ & (0.1 to 0.2$)$ & $\begin{array}{l}(-11.7 \text { to } \\
21.6)\end{array}$ & $\begin{array}{l}(0.1 \text { to } \\
0.2)\end{array}$ & $\begin{array}{l}(60.1 \text { to } \\
129.4)^{\star}\end{array}$ & (1.1 to 3.0$)$ & $\begin{array}{l}(-20.6 \text { to } \\
12.0)\end{array}$ \\
\hline
\end{tabular}

*indicates statistically significant change.

Abbreviations: DALYs = disability-adjusted life years; NASH = non-alcoholic steatohepatitis 


\begin{tabular}{|c|c|c|c|c|c|c|c|c|}
\hline \multirow{2}{*}{$\begin{array}{l}\text { Risk- } \\
\text { outcome } \\
\text { pairs }\end{array}$} & \multicolumn{4}{|l|}{ Deaths } & \multicolumn{4}{|l|}{ DALYs } \\
\hline & $\begin{array}{l}2019 \\
\text { all } \\
\text { ages } \\
\text { number } \\
\left(\times 10^{3}\right)\end{array}$ & $\begin{array}{l}\text { Change\% } \\
\text { in all } \\
\text { ages } \\
\text { number, } \\
1990- \\
2019\end{array}$ & $\begin{array}{l}2019 \text { age- } \\
\text { standardized } \\
\text { rate per } \\
100,000 \\
\text { people }\end{array}$ & $\begin{array}{l}\text { Change\% in } \\
\text { age- } \\
\text { standardized } \\
\text { rate, 1990- } \\
2019\end{array}$ & $\begin{array}{l}2019 \\
\text { all } \\
\text { ages } \\
\text { number } \\
\left(\times 10^{6}\right)\end{array}$ & $\begin{array}{l}\text { Change\% } \\
\text { in all } \\
\text { ages } \\
\text { number, } \\
1990- \\
2019\end{array}$ & $\begin{array}{l}2019 \text { age- } \\
\text { standardized } \\
\text { rate per } \\
100,000 \\
\text { people }\end{array}$ & $\begin{array}{l}\text { Change\% in } \\
\text { age- } \\
\text { standardized } \\
\text { rate, 1990- } \\
2019\end{array}$ \\
\hline \multirow[t]{2}{*}{ Smoking } & 5.0 & 92.3 & 0.1 & -7.9 & 0.1 & 70.5 & 1.3 & -16.2 \\
\hline & $\begin{array}{l}(2.8 \text { to } \\
7.5)\end{array}$ & $\begin{array}{l}\text { (64.9 to } \\
127.9)^{*}\end{array}$ & (0.0 to 0.1 ) & $\begin{array}{l}(-20.3 \text { to } \\
7.3)\end{array}$ & $\begin{array}{l}(0.1 \text { to } \\
0.2)\end{array}$ & $\begin{array}{l}(44.6 \text { to } \\
103.1)^{\star}\end{array}$ & (0.7 to 2.0 ) & $\begin{array}{l}(-28.3 \\
\text { to }-1.4)^{*}\end{array}$ \\
\hline \multirow{2}{*}{$\begin{array}{l}\text { High } \\
\text { fasting } \\
\text { plasma } \\
\text { glucose }\end{array}$} & 3.0 & 196.5 & 0.0 & 38.5 & 0.1 & 164.3 & 0.7 & 27.8 \\
\hline & $\begin{array}{l}(0.7 \text { to } \\
6.9)\end{array}$ & $\begin{array}{l}(160.7 \text { to } \\
246.0)^{\star}\end{array}$ & (0.0 to 0.1 ) & $\begin{array}{l}(23.1 \text { to } \\
61.2)^{\star}\end{array}$ & $\begin{array}{l}(0.0 \text { to } \\
0.1)\end{array}$ & $\begin{array}{l}(130.7 \text { to } \\
212.2)^{\star}\end{array}$ & (0.2 to 1.7 ) & $\begin{array}{l}(11.8 \text { to } \\
50.6)^{\star}\end{array}$ \\
\hline \multirow{2}{*}{$\begin{array}{l}\text { Liver } \\
\text { cancer } \\
\text { due to } \\
\text { other } \\
\text { causes }\end{array}$} & 7.0 & 55.9 & 0.1 & -23.1 & 0.2 & 39.4 & 2.2 & -29.2 \\
\hline & $\begin{array}{l}(4.5 \text { to } \\
10.3)\end{array}$ & $\begin{array}{l}(27.4 \text { to } \\
93.6)^{\star}\end{array}$ & $(0.1$ to 0.2$)$ & $\begin{array}{l}(-36.9 \\
\text { to }-5.6) \star\end{array}$ & $\begin{array}{l}(0.1 \text { to } \\
0.3)\end{array}$ & $\begin{array}{l}(12.0 \text { to } \\
78.1)^{\star}\end{array}$ & $(1.4$ to 3.2$)$ & $\begin{array}{l}(-42.7 \\
\text { to }-10.8)^{*}\end{array}$ \\
\hline \multirow[t]{2}{*}{ Smoking } & 3.2 & 21.3 & 0.0 & -40.2 & 0.1 & 6.8 & 1.0 & -46.2 \\
\hline & $\begin{array}{l}(1.2 \text { to } \\
5.7)\end{array}$ & $\begin{array}{l}(-2.7 \text { to } \\
52.3)\end{array}$ & (0.0 to 0.1 ) & $\begin{array}{l}(-5.8 \text { to } \\
78.0)\end{array}$ & $\begin{array}{l}(0.0 \text { to } \\
0.1)\end{array}$ & $\begin{array}{l}(-15.5 \text { to } \\
38.2)\end{array}$ & (0.5 to 1.5 ) & $\begin{array}{l}(-57.0 \text { to } \\
101.8)\end{array}$ \\
\hline \multirow{2}{*}{$\begin{array}{l}\text { High } \\
\text { fasting } \\
\text { plasma } \\
\text { glucose }\end{array}$} & 1.7 & 74.5 & 0.0 & -15.5 & 0.0 & 52.9 & 0.5 & -23.9 \\
\hline & $\begin{array}{l}(0.4 \text { to } \\
3.7)\end{array}$ & $\begin{array}{l}(47.8 \text { to } \\
109.0)^{\star}\end{array}$ & (0.0 to 0.0$)$ & $\begin{array}{l}(-51.6 \\
\text { to-25.5)* }\end{array}$ & $\begin{array}{l}(0.0 \text { to } \\
0.1)\end{array}$ & $\begin{array}{l}(27.9 \text { to } \\
84.7)^{\star}\end{array}$ & (0.1 to 1.0 ) & $\begin{array}{l}(-36.2 \\
\text { to-31.7)* }\end{array}$ \\
\hline \multirow{2}{*}{$\begin{array}{l}\text { High } \\
\text { body- } \\
\text { mass } \\
\text { index }\end{array}$} & 3.0 & 143.6 & 0.0 & 21.4 & 0.1 & 118.8 & 1.0 & 13.7 \\
\hline & $\begin{array}{l}(1.2 \text { to } \\
5.7)\end{array}$ & $\begin{array}{l}(80.2 \text { to } \\
286.2)^{\star}\end{array}$ & (0.0 to 0.1 ) & $\begin{array}{l}(-9.3 \text { to } \\
89.5)\end{array}$ & $\begin{array}{l}(0.0 \text { to } \\
0.2)\end{array}$ & $\begin{array}{l}(57.2 \text { to } \\
261.5)^{\star}\end{array}$ & (0.4 to 1.9$)$ & $\begin{array}{l}(-17.5 \text { to } \\
85.8)\end{array}$ \\
\hline \multicolumn{9}{|c|}{ *indicates statistically significant change. } \\
\hline \multicolumn{9}{|c|}{ Abbreviations: DALYs = disability-adjusted life years; NASH = non-alcoholic steatohepatitis } \\
\hline
\end{tabular}

With respect to different etiologies, smoking contributed more than half of LCHB burden, followed by high BMI (35.7\%) and alcohol use (8.6\%). Drug use accounted for $63.0 \%$ of LCHC burden, followed by smoking (18.8\%) and high BMI (17.5\%). For LCAU, alcohol use had the greatest contribution (73.8\%), and other related risks were smoking (14.0\%) and high BMI (12.2\%). Smoking (64.4\%) and high fasting plasma glucose (35.6\%) contributed to LCNA burden, whereas for LCOC, the related risks included high BMI (41.0\%), smoking (40.1\%), and high fasting plasma glucose (18.9\%) (Supplementary Figure S1).

\section{Global Exposure Level To The Risk Factors}

Exposure to alcohol use was high in Europe, Australasia, and high-income North America, with Estonia (ASR of SEV $=19.9 \%$ ), Czechia (19.9\%), and Germany (19.4\%) the highest. For drug use, high-income North America, North Africa, and the Middle East had high exposure levels, with three countries having the highest levels being USA (1.2\%), Canada (0.6\%), and Australia (0.6\%). High levels of high BMI exposure were observed especially in high-income North America, and Australasia, with Qatar (56.5\%), United Arab Emirates (53.6\%), and Kuwait (53.5\%) having the highest levels. Exposure to high fasting plasma glucose was high in Oceania, Sub-Saharan Africa, and Central and Southeast Asia, with Marshall Islands (38.4\%), American Samoa $(37.2 \%)$, and Niue (32.4\%) the highest. Exposure to smoking was high in Europe, and Southern Latin America, with the highest rates in Montenegro (24.6\%), Greece (23.5\%), and Bosnia and Herzegovina (22.9\%) (Fig. 1). 


\section{Global Lc Burden By Sex And Age Group}

The LC burden in males (120.9) was more than three times that in females (32.5) in 2019, in terms of age-standardized DALY rates. From 1990 to 2019, the LC burden in females and males demonstrated a trend of first increasing and then decreasing. The general ranking of LC burden due to risk factors was similar in both sexes. However, drug use attributed LC burden has been increasing in females from 1990, and then decreased in the past decade, and the alcohol use attributed burden has gradually decreased from 1990 to 2019 (Fig. 2).

The LC burden was mainly concentrated in the 45 to 69 years old age group with the heaviest in the 60 to 64 years old for males and the 65 to 69 years old for females (Fig. 3). Overall, LC burden increased with age from 20 to 60 years old and decreased with age after 60 years old. Among patients over 50 years old, LC burden attributable to drug use increased and burden attributable to high BMI decreased in males.

\section{Regional And National Lc Burden}

In 1990, the risk attributed LC burden was the highest in East Asia, followed by high-income Asia Pacific, and the lowest in Central Sub-Saharan Africa and Southern Latin America, in terms of DALYs. With respect to specific etiologies, LCHB burden was the highest in East Asia and Oceania; LCHC burden was the highest in high-income Asia Pacific, North Africa and the Middle East; and LCAU burden was the highest in the 17 remaining GBD regions. The highest risk attributed LC burden was observed in Mongolia, Sierra Leone, and Burkina Faso.

By contrast, Central Asia and High-income Asia Pacific had the highest risk attributable LC burden in 2019, and the lowest burden was in Central Sub-Saharan Africa and Eastern Sub-Saharan Africa. LCHB burden was still the highest in East Asia; LCHC burden was the highest in high-income Asia Pacific, North Africa and the Middle East and Oceania; and LCAU burden was the highest in the 17 remaining GBD regions (Fig. 4). The three countries with the heaviest risk-related LC burden were Mongolia, Gambia, and Tonga in 2019.

\section{Trends Of Risk-related Lc Burden}

Globally, total risk factors attributed LC burden increased from 1990 to 2000, then decreased from 2001 to 2005, and remained stable. In low SDI regions, LC burden remained stable, while it first increased and then gradually stabilized in high SDI regions, and other regions remained consistent with global trend (Fig. 5).

LC burden due to high BMI, and high fasting plasma glucose continued to grow from 2005 to 2019. Burden due to alcohol use and drug use fell after 2000, and rose slightly from 2005 to 2019, while burden due to smoking continued to reduce from 2005, in terms of ASDR. For alcohol use, drug use, and high BMI, the related LC burden was the highest in the high SDI region, and was the lowest in the low SDI region. For high fasting plasma glucose and smoking, middle SDI region had the highest burden. (Supplementary Figure S2).

\section{Relationship Between Risk-related Lc Burden And Social Development}

In general, the SEVs of drug use and high BMI increased with SDI, whereas the alcohol use and smoking exposure levels first increased with increasing SDI and decreased when the SDI became $>0.8$. In particular, the high fasting plasma glucose SEV decreased with an increase in the SDI value from 0.5 to 0.8 (Fig. 6).

In terms of the DALY rates, the relationship between the overall LC burden with SDI was roughly similar to that of LC by different causes. The risk-related burden first increased as SDI increased from 0.2 to 0.5 , then decreased as SDI ranged from 0.5 to 0.7 , and increased again after the SDI value became > 0.7 (Supplementary Figure S3). 


\section{Discussion}

The worldwide LC burden remains serious, and several prognostic risk factors have significantly contributed to this over the years. In the present study, we evaluated exposure levels of the five recognized risk factors, the risk-related LC burden, and temporal trends from 1990 to 2019, as well as the specific contribution to each LC subtype. Generally, the five risk factors contributed to nearly half of the total LC burden, with alcohol use as the greatest risk factor, followed by smoking. The increase in risk attributed LC burden showed significant differences among different sexes, age groups, and SDI regions. In addition, exposure level, attributable LC burden, and SDI were significantly correlated. Therefore, recognizing risk factors that increase LC burden is important in improving the disease prognosis.

Previous studies have focused on LC burden by different etiologies, whereas our study shifted the emphasis to the risk factors that increased LC burden. Consistent with previous literature, the distribution of risk attributed LC burden is similar to the total LC burden, with East Asia exhibiting the highest burden among the regions worldwide where HBV is an epidemic[9]. These findings demonstrated that the measures taken to reduce HCV and HBV infection have achieved good results. Among the risk factors, drug use has a certain influence[10]. Nevertheless, a lag effect may have been existing after the implementation of the controlling policies. High fasting plasma glucose was the risk factor with the least contribution, exhibiting a difference only in LCNA and LCOC[11]. Although the change is minimal, burden due to high fasting plasma glucose has been increasing over the years, especially in the high SDI regions[12]. From here on, we will discuss the three risk factors with the greatest contribution to LC burden.

Smoking is a risk factor especially in LCHB and LCNA. Large cohort studies have shown that smoking was significantly associated with impaired quality of life in HCC patients[13] and smoking history was an independent prognostic factor in HBV/HCV-infected HCC patients[14]. Moreover, other studies indicated that smoking was associated with increased non-graft related mortality after liver transplantation[15]. Possible explanations to date included the effect of smoking on increased fibrosis, age, fitness, and compliance difference between the two groups[16]. The smoking-related LC burden has declined in the last decade owing to aggressive smoking cessation and tobacco control policies in various countries worldwide[17]. However, the contribution of smoking to LC burden is still non-negligible, especially among middle-aged and elderly. Taken together, these findings strongly suggest that smoking cessation should be considered as an important element of healthy living habits that must be fully implemented.

Large-scale cohort studies have demonstrated the association between high BMI and the prognosis of LC[18]. A significant increase in high BMI attributed LC mortality was observed in our study, which was consistent with the rising exposure level of high BMI. In this case, the risks of LC morbidity and mortality due to high BMI would continue to increase without effective interventions[19]. Moreover, the reduction in LC burden due to the national prevention and control of HBV and HCV infections might be offset by high BMI, especially in developed countries, where LC exhibited a prominent upward trend and high BMI exposure may have worsened the problem[19]. Therefore, it is imperative to adopt policies to prevent and control obesity including governments emphasizing the seriousness of the obesity problem, increasing related research funding, and raising public awareness[20].

Alcohol use and obesity have a synergistic role in the development of liver diseases[15]. Alcohol consumption is not only an etiology but also a vital prognostic factor for LC, accounting for nearly $15 \%$ of LC cases and $25 \%$ of risk-related DALYs worldwide. Our study indicated that alcohol use attributed LC deaths doubled from 1990 to 2019, whereas the related ASDR slightly decreased during this period. This discrepancy might be the result of the acceleration of population aging worldwide[21, 22]. Globally, alcohol consumption is roughly consistent with the distribution of alcohol use-related LC burden[24]. However, in some other countries like China, a converse association between alcohol consumption and related LC burden was observed. This mismatch might be explained by the following reasons: (1) these countries are dominated by LCHB, where alcohol use has little effect; (2) LC development is a long process, and alcohol consumption has increased in these countries only in recent years, with its effect not being fully demonstrated yet. 
Several limitations need to be addressed in this study. First, there may be some prognostic risk factors that have a role in LC but are not yet recognized and thus were not included in this research. Second, the interactions between these risk factors are not taken into account in the estimation of LC burden, leading to the possibility of overestimation. Third, there was no pathology-related analysis in our study owing to the lack of pathological information in the database. Regardless of these deficiencies, the current study has provided the most comprehensive and in-depth analysis of global LC burden and its related prognostic risk factors, filling in the gaps in previous studies.

\section{Conclusion}

In summary, the recognized risk factors significantly contributed to the global burden of LC. On the one hand, the total LC burden attributable to the risk factors has gone through a process of increasing and decreasing, and has reached a stable state in the last decade. And the LC burden attributable to smoking have particularly shown a downward trend in the recent years. On the other hand, the risk-related burden in males was more than three times as that in females, and the regions of Central Asia, high-income Asia Pacific and East Asia exhibited the highest burden worldwide. In addition, both the exposure level and the LC burden attributable to the risk factors were associated with the SDI. The findings of this study could help in understanding the role of prognostic risk factors in LC burden, promoting the development of relevant studies, and proposing better prevention and control policies tailored to local conditions.

\section{Declarations}

\section{Ethics approval and consent to participate}

This paper is exempt from ethical committee approval, because it is based on the GBD 2019 database, which does not contain identifiable personal information, and a waiver of informed consent was reviewed and approved by the Institutional Review Board of the University of Washington.

\section{Consent for publication}

Not applicable

\section{Availability of data and materials}

The datasets supporting the conclusions of this article are included within the article.

\section{Competing interests}

The authors declared that they have no conflict of interests.

\section{Funding}

None

\section{Authors' contributions}

YZL, ZJ D: study design and concept. BJ W, YJ D: statistical analysis. YZ L: drafting of manuscript. YX L, XY D, DX, JJ H: data interpretation. YZ, PX, JY, ZZ, LH Z, SY, YW, SS Z, ZJ D: critically revising the manuscript. All authors read and approved the final version of the manuscript.

\section{Acknowledgements}

We highly appreciated the works by the Global Burden of Disease Study 2019 collaborators.

\section{References}


1. Global, regional, and national incidence, prevalence, and years lived with disability for 354 diseases and injuries for 195 countries and territories, 1990-2017: a systematic analysis for the Global Burden of Disease Study 2017. Lancet (London, England) 2018, 392, 1789-1858, doi:10.1016/s0140-6736(18)32279-7.

2. Kulik, L.; El-Serag, H.B. Epidemiology and Management of Hepatocellular Carcinoma. Gastroenterology 2019, 156, doi:10.1053/j.gastro.2018.08.065.

3. Schweitzer, A.; Horn, J.; Mikolajczyk, R.; Krause, G.; Ott, J. Estimations of worldwide prevalence of chronic hepatitis B virus infection: a systematic review of data published between 1965 and 2013. Lancet (London, England) 2015, 386, 15461555, doi:10.1016/s0140-6736(15)61412-x.

4. Kim, S.R.; Kudo, M.; Hino, O.; Han, K.H.; Chung, Y.H.; Lee, H.S. Epidemiology of hepatocellular carcinoma in Japan and Korea. A review. Oncology 2008, 75 Supp/ 1, 13-16, doi:10.1159/000173419.

5. Liu, Z.; Jiang, Y.; Yuan, H.; Fang, Q.; Cai, N.; Suo, C.; Jin, L.; Zhang, T.; Chen, X. The trends in incidence of primary liver cancer caused by specific etiologies: Results from the Global Burden of Disease Study 2016 and implications for liver cancer prevention. Journal of hepatology 2019, 70,674-683, doi:10.1016/j.jhep.2018.12.001.

6. Global burden of 87 risk factors in 204 countries and territories, 1990-2019: a systematic analysis for the Global Burden of Disease Study 2019. Lancet (London, England) 2020, 396, 1223-1249, doi:10.1016/s0140-6736(20)30752-2.

7. The global burden of disease attributable to alcohol and drug use in 195 countries and territories, 1990-2016: a systematic analysis for the Global Burden of Disease Study 2016. Lancet Psychiatry 2018, 5, doi:10.1016/S22150366(18)30337-7.

8. Deng, Y.; Zhao, P.; Zhou, L.; Xiang, D.; Hu, J.; Liu, Y.; Ruan, J.; Ye, X.; Zheng, Y.; Yao, J., et al. Epidemiological trends of tracheal, bronchus, and lung cancer at the global, regional, and national levels: a population-based study. Journal of hematology \& oncology 2020, 13, 98, doi:10.1186/s13045-020-00915-0.

9. Bertuccio, P.; Turati, F.; Carioli, G.; Rodriguez, T.; La Vecchia, C.; Malvezzi, M.; Negri, E. Global trends and predictions in hepatocellular carcinoma mortality. Journal of hepatology 2017, 67, 302-309, doi:10.1016/j.jhep.2017.03.011.

10. Spearman, C.W.; Dusheiko, G.M.; Hellard, M.; Sonderup, M. Hepatitis C. Lancet (London, England) 2019, 394, 1451-1466, doi:10.1016/S0140-6736(19)32320-7.

11. Yang, W.S.; Zeng, X.F.; Liu, Z.N.; Zhao, Q.H.; Tan, Y.T.; Gao, J.; Li, H.L.; Xiang, Y.B. Diet and liver cancer risk: a narrative review of epidemiological evidence. Br J Nutr 2020, 124, 330-340, doi:10.1017/s0007114520001208.

12. Okeke, E.; Davwar, P.M.; Roberts, L.; Sartorius, K.; Spearman, W.; Malu, A.; Duguru, M. Epidemiology of Liver Cancer in Africa: Current and Future Trends. Semin Liver Dis 2020, 40, 111-123, doi:10.1055/s-0039-3399566.

13. Li, I.; Huang, J.; Chen, J.; Wang, T.; Huang, S.; Tsay, S. Factors related to the quality of life in liver cancer patients during treatment phase: A follow-up study. European journal of cancer care 2019, 28, e13146, doi:10.1111/ecc.13146.

14. Liu, X.; Hou, Y.; Wang, X.; Yu, L.; Wang, X.; Jiang, L.; Yang, Z. Machine learning-based development and validation of a scoring system for progression-free survival in liver cancer. Hepatology international 2020, 14, 567-576, doi:10.1007/s12072-020-10046-w.

15. Kolly, P.; Knöpfli, M.; Dufour, J.-F. Effect of smoking on survival of patients with hepatocellular carcinoma. Liver Int 2017, 37, 1682-1687, doi:10.1111/liv.13466.

16. Sinn, D.H.; Kang, D.; Cho, S.J.; Paik, S.W.; Guallar, E.; Cho, J.; Gwak, G.-Y. Risk of hepatocellular carcinoma in individuals without traditional risk factors: development and validation of a novel risk score. International journal of epidemiology 2020, 10.1093/ije/dyaa089, doi:10.1093/ije/dyaa089.

17. Yang, J.; Hainaut, P.; Gores, G.; Amadou, A.; Plymoth, A.; Roberts, L. A global view of hepatocellular carcinoma: trends, risk, prevention and management. Nature reviews. Gastroenterology \& hepatology 2019, 16, 589-604, doi:10.1038/s41575-0190186-y.

18. Kim, K.; Choi, S.; Park, S.M. Association of High Body Mass Index and Hepatocellular Carcinoma in Patients With Chronic Hepatitis B Virus Infection: A Korean Population-Based Cohort Study. JAMA oncology 2018, 4, 737-739, doi:10.1001/jamaoncol.2018.0035.

Page $11 / 18$ 
19. Utsunomiya, T.; Okamoto, M.; Kameyama, T.; Matsuyama, A.; Yamamoto, M.; Fujiwara, M.; Mori, M.; Aimitsu, S.; Ishida, T. Impact of obesity on the surgical outcome following repeat hepatic resection in Japanese patients with recurrent hepatocellular carcinoma. World J Gastroentero/ 2008, 14, 1553-1558.

20. Zhang, G.; Cao, F.; Shi, L.; Ma, T.; Zhang, L. Contribution of high body mass index and alcohol use to liver cancer-related mortality: A study based on 195 countries or territories. Digestive and liver disease : official journal of the Italian Society of Gastroenterology and the Italian Association for the Study of the Liver 2020, 52, 221-231, doi:10.1016/j.dld.2019.10.012.

21. Tandon, P.; Berzigotti, A. Management of Lifestyle Factors in Individuals with Cirrhosis: A Pragmatic Review. Semin Liver Dis 2020, 40, 20-28, doi:10.1055/s-0039-1696639.

22. Melo, A.; França, E.; Malta, D.; Garcia, L.; Mooney, M.; Naghavi, M. Mortality due to cirrhosis, liver cancer, and disorders attributed to alcohol use: Global Burden of Disease in Brazil, 1990 and 2015. Revista brasileira de epidemiologia = Brazilian journal of epidemiology 2017, 10.1590/1980-5497201700050006, 61-74, doi:10.1590/19805497201700050006.

23. Sun, Y.; Wang, Y.; Li, M.; Cheng, K.; Zhao, X.; Zheng, Y.; Liu, Y.; Lei, S.; Wang, L. Long-term trends of liver cancer mortality by gender in urban and rural areas in China: an age-period-cohort analysis. BMJ open 2018, 8, e020490, doi:10.1136/bmjopen-2017-020490.

24. Paik, J.M.; Golabi, P.; Younossi, Y.; Mishra, A.; Younossi, Z.M. Changes in the Global Burden of Chronic Liver Diseases From 2012 to 2017: The Growing Impact of Nonalcoholic Fatty Liver Disease. Hepatology (Baltimore, Md.) 2020, 10.1002/hep.31173, doi:10.1002/hep.31173.

\section{Figures}




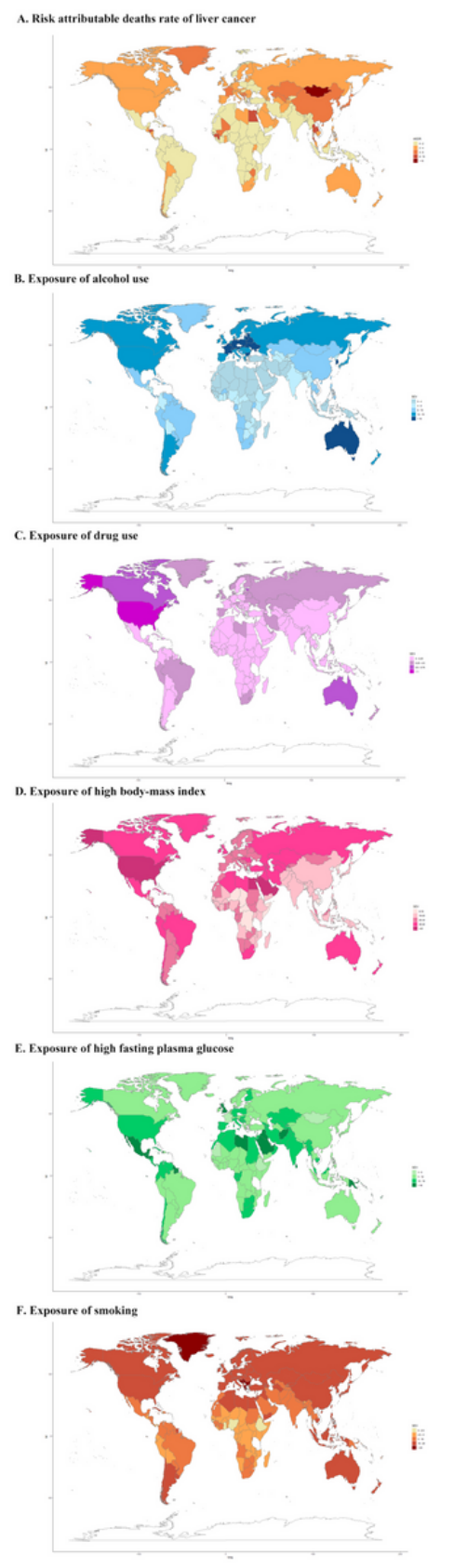

\section{Figure 1}

Age-standardized death rate of total risk factors related liver cancer burden and the exposure levels of the five recognized risk factors for both sexes in 204 countries and territories, 2019. (A) total risk related liver cancer burden; (B) exposure level of alcohol use; (C) exposure level of drug use; (D) exposure level of high body-mass index; (E) exposure level of high fasting plasma glucose; (F) exposure level of smoking. Abbreviations: ASDR, age-standardized death rate; SEV: summary exposure value. 


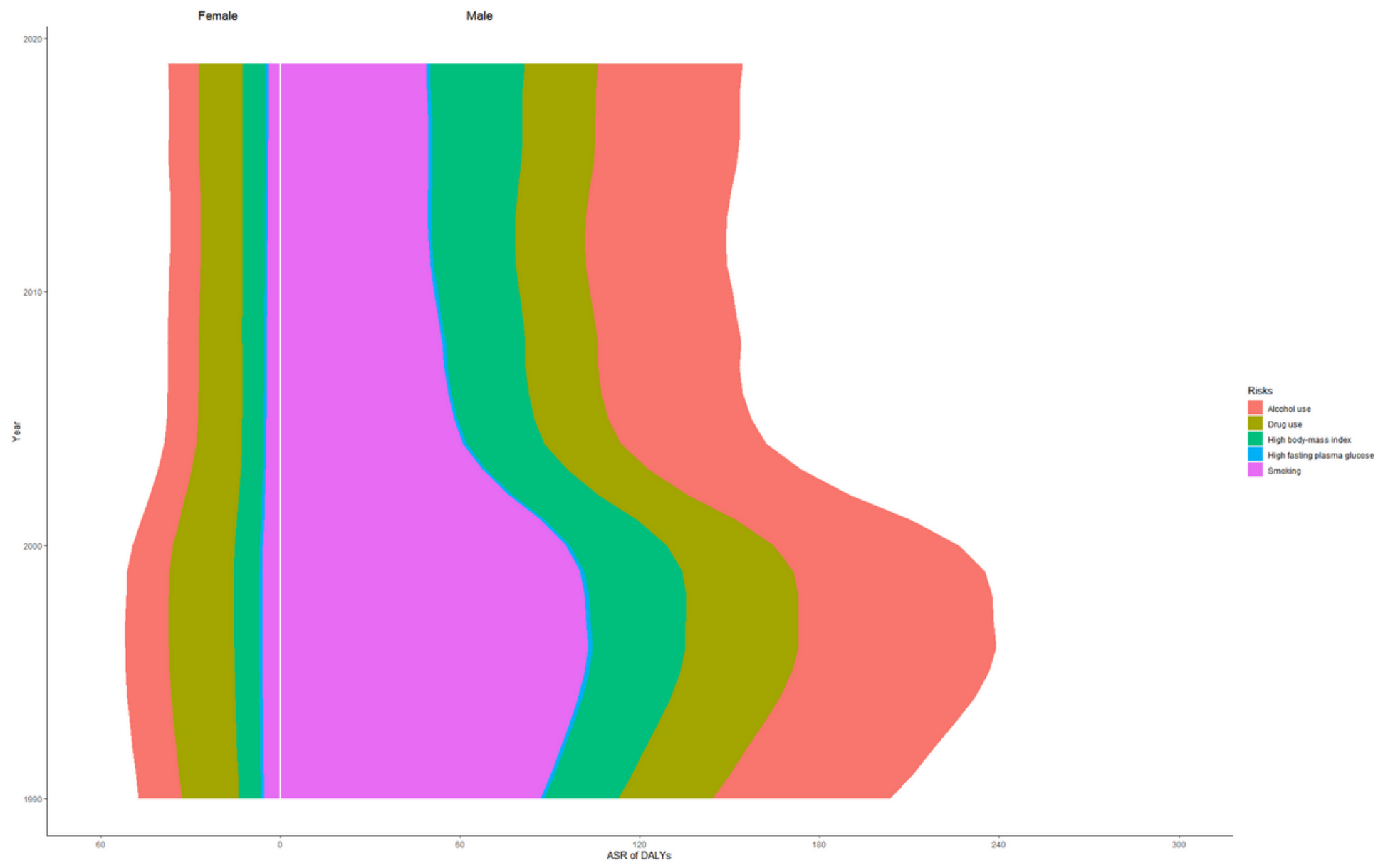

Figure 2

Comparison of changes in age-standardized DALY rate of liver cancer due to each of the five recognized risk factors between males and females, from 1990 to 2019. Abbreviation: ASR, age-standardized rate; DALY, disability-adjusted life year. 


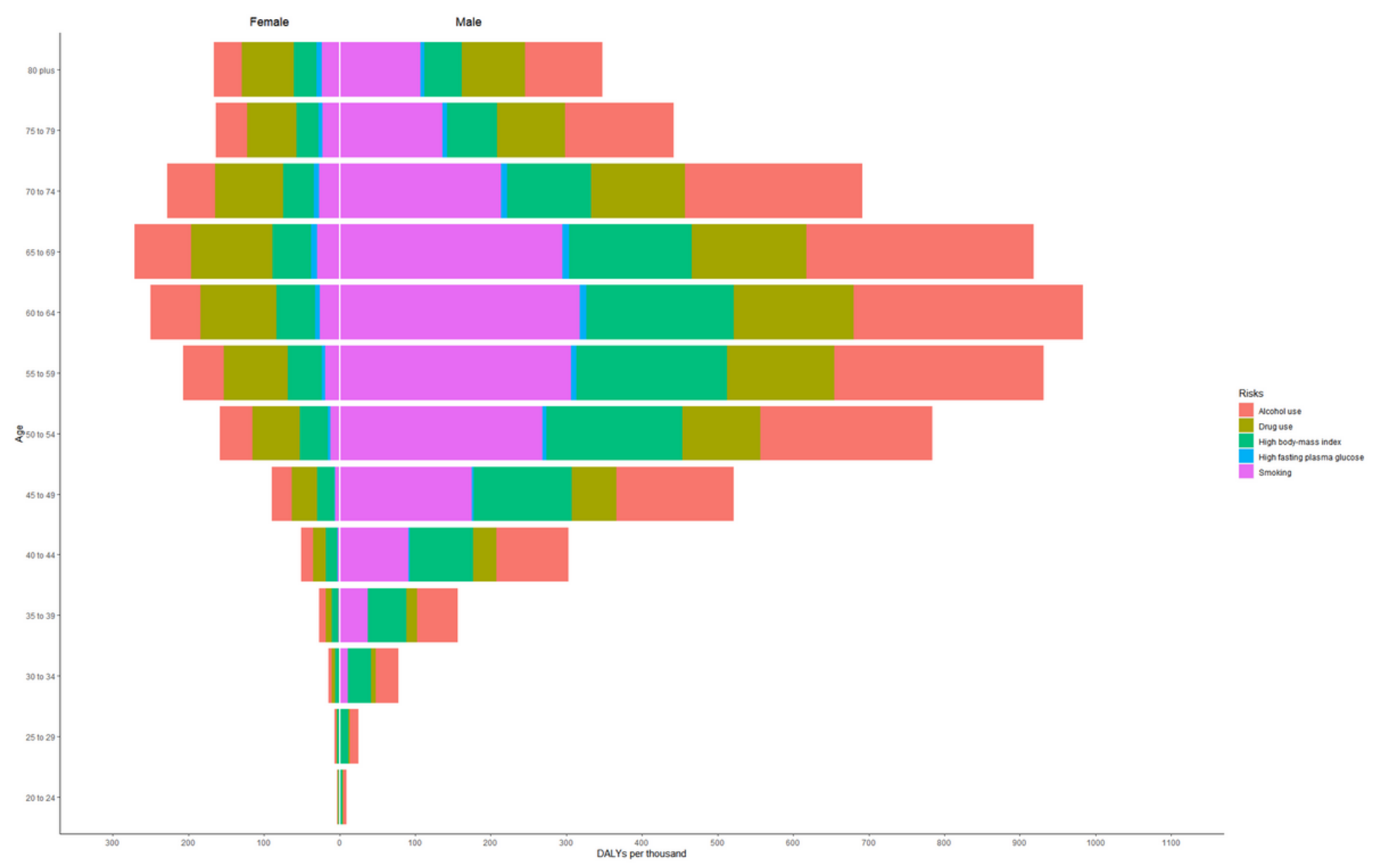

Figure 3

The proportion of risk factors related liver cancer burden, in terms of DALYs numbers, in each age group, between males and females, 2019. Every five years is divided into an age group in population over the age of 20. 

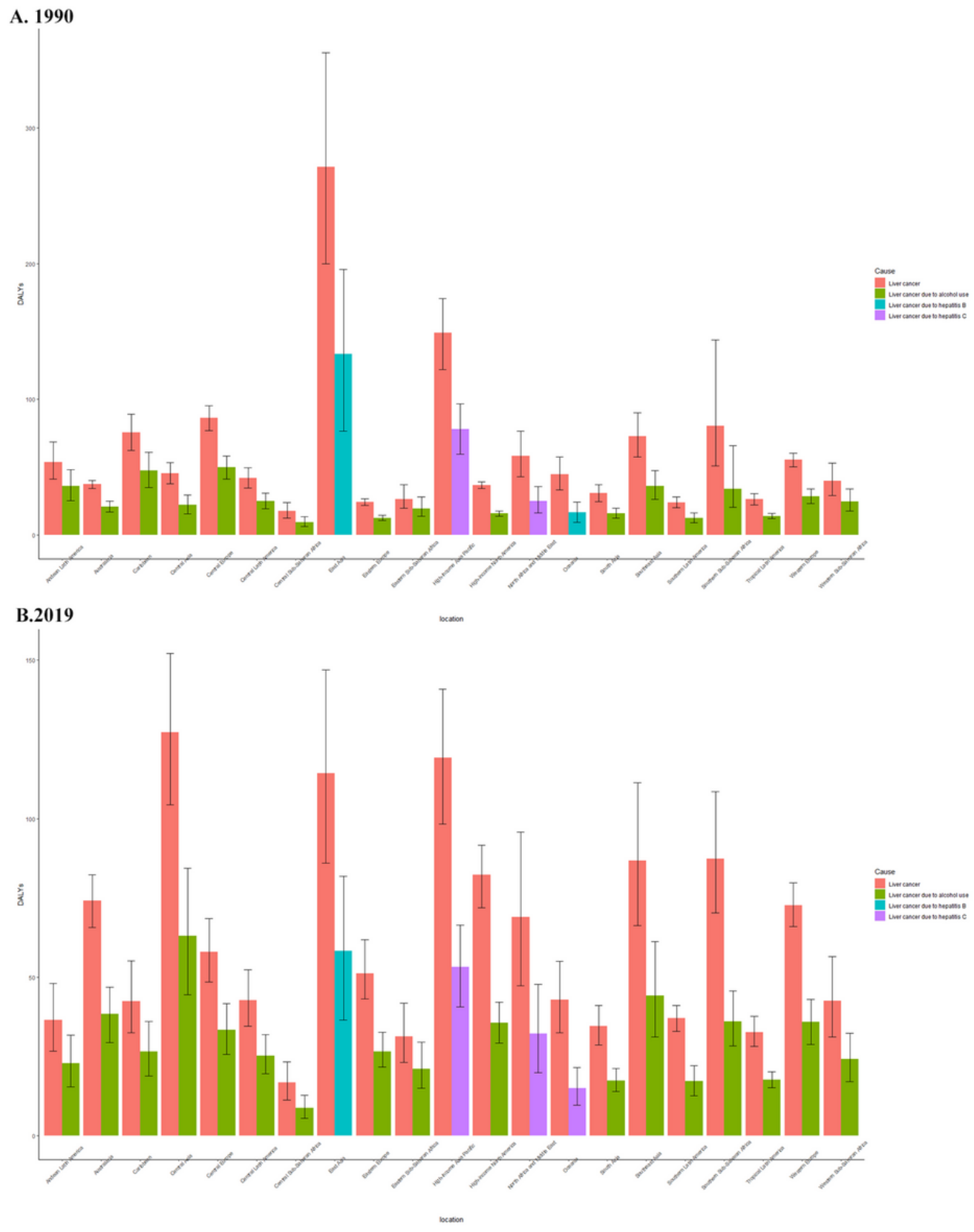

Figure 4

The proportion of risk factors-related liver cancer DALYs by etiologies in 21 GBD regions, comparison between 1990 and 2019. (A) proportion of risks-related liver cancer DALYs in 1990; (B) proportion of risks-related liver cancer DALYs in 2019. Abbreviation: DALYs, disability-adjusted life years. 


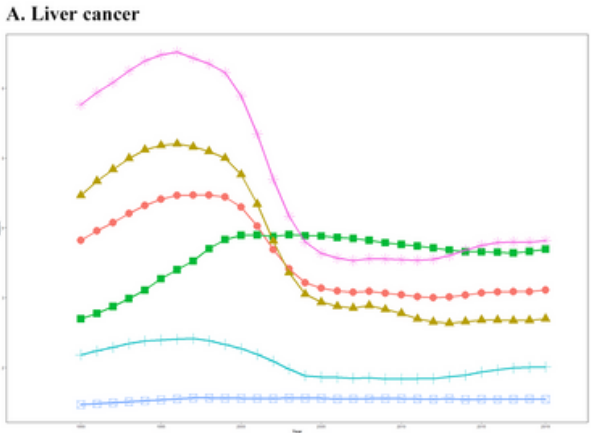

D. Liver cancer due to hepatitis C

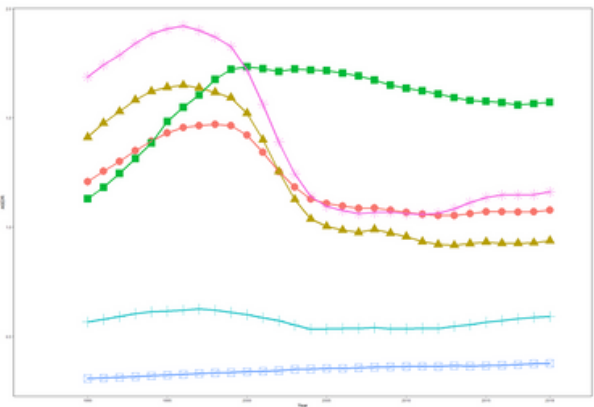

B. Liver cancer due to alcohol use

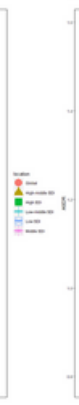

E. Liver cancer due to NASH

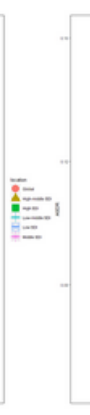

C. Liver cancer due to hepatitis B

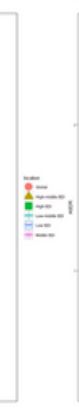

F. Liver cancer due to other causes

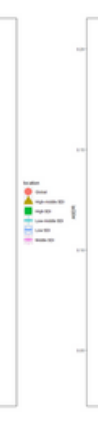

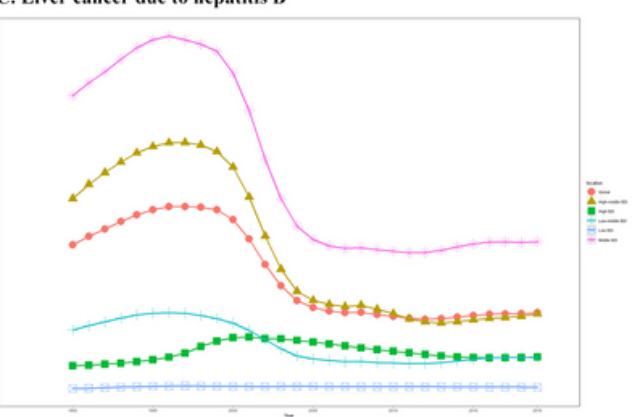

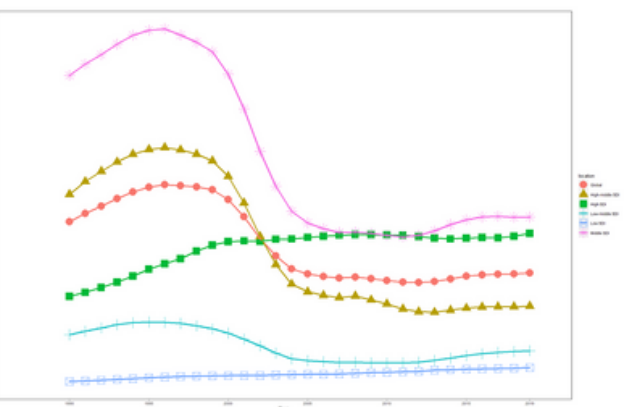

Figure 5

The variation trends of risk attributable liver cancer burden by causes from 1990 to 2019. (A) total liver cancer; (B) liver cancer due to alcohol use; (C) liver cancer due to hepatitis B; (D) liver cancer due to hepatitis C; (E) liver cancer due to NASH; (F) liver cancer due to other causes. Abbreviation: ASDR, age-standardized death rate; NASH, non-alcoholic steatohepatitis; SDI, social demographic index. 

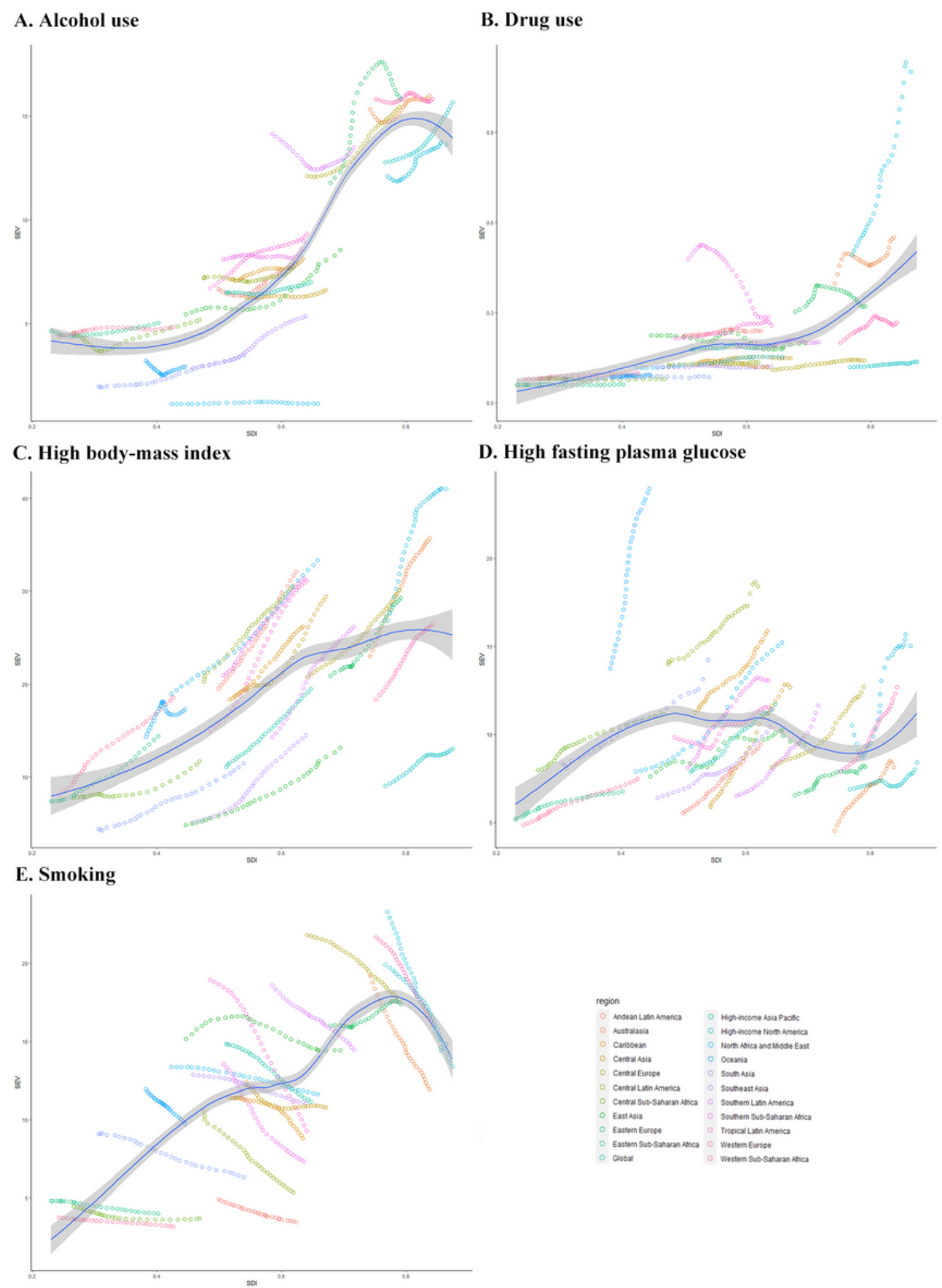

\section{Figure 6}

Co-variation of SEV and SDI for the five recognized risk factors in 2019. Coloured circles represents SEVs for global and 21 GBD regions. Each circle represents one year in the time intervals from 1990 to 2019. The blue line represents the average expected SEV based on SDI alone. Abbreviations: SEV, summary exposure value; SDI, social demographic index; GBD, Global Burden of Disease.

\section{Supplementary Files}

This is a list of supplementary files associated with this preprint. Click to download.

- SupplementaryFigureS1.tif

- SupplementaryFigureS2.tif

- SupplementaryFigureS3.tif 